\title{
The Importance of Clinical and Biochemical Markers in the Diagnosis of Disorders of the Psychomotor and Physical Development of Children who Underwent Perinatal CNS Lesions
}

\author{
Olga N. Krasnorutskaya, PhD*; Vera S. Ledneva, PhD, ScD; Daniil Yu. Bugrimov, PhD; \\ Elena A. Balakireva, PhD, ScD; Anna A. Zuikova, PhD, ScD; \\ Julia A. Kotova, PhD; Natalia V. Strahova, PhD \\ Voronezh State Medical University named after N.N. Burdenko \\ Voronezh, the Russian Federation
}

\begin{abstract}
The purpose of this study was to evaluate the blood level of neurotrophic factors (S100 protein, nerve growth factor, Lhomocysteine and angiotensin II) in the diagnosis of disorders of the psychomotor and physical development of children who underwent perinatal CNS lesions.A comprehensive approach to assessing the blood levels of neurotrophic factors, along with methods of neuroimaging in children in the first 6 months of the postnatal period, allows identification of the total result of multidirectional degenerative-reparative processes in the neurovascular components of CNS and construction of the diagnostically significant criteria of the severity of neuropathology, which determines the physical development of children in the first year of life. (International Journal of Biomedicine. 2018;8(2):129-133.)
\end{abstract}

Key Words: central nervous system $\bullet$ perinatal lesions $\bullet$ biochemical markers $\bullet$ neurotrophic factors

\section{Abbreviations}

AII, angiotensin II; CNS, central nervous system; Hcy, homocysteine; ND, neurological deficit; NGF, nerve growth factor.

\section{Introduction}

A reliable system of early diagnosis, based on a comprehensive analysis of circulating biochemical markers of brain damage in infants, is an important criterion of the effectiveness of therapeutic/preventive measures aimed at preventing the development of disorders in children who underwent perinatal lesions of CNS. This system of early diagnosis should be convenient to use and interpret and available at any level of health care. ${ }^{(1,2)}$ The microcirculatory insufficiency in childbirth and the antenatal period is the

*Corresponding author: Olga N. Krasnorutskaya, PhD. Voronezh State Medical University named after N.N. Burdenko. Voronezh, the Russian Federation. E-mail: onkrasnorutckaja@ rambler.ru dominant link in the development of degenerative processes in CNS of newborns, which requires a more detailed analysis of the variability of neurovascular markers that reflect the formation of adaptation processes of the body. ${ }^{(3)}$ The capillary endothelium of the brain is extremely sensitive to ischemichypoxic effects, and its pathology occupies leading positions in the formation of neurological disorders. ${ }^{(4,5)}$ Homocysteine (Hcy) and angiotensin II (AII) are leading markers in the diagnosis of the pathomorphological state and function of the endothelium of the microcirculatory bed. They are released in high concentrations during damage to capillary structures, causing disruption of the passage of nerve impulses between neurons of the brain through myelination of the axonal structures of the white matter, which affects the metabolism of nerve cells and the regenerative potential of astrocytic glia, manifested by the variability in the blood levels of S100 protein 
and NGF.(6) An increase in the Hcy level is directly related to the activity of the enzyme cystathionine beta-synthase, which is involved in the metabolism of white substance myelin structures. Therefore, hyperhomocysteinemia is direct evidence of the impaired conduction and synergy of nerve impulses between neurons in brain structures.(7) An increase in the AII level is a direct consequence of hyperhomocysteinemia, which provokes a cytotoxic effect on the vascular endothelium, which in turn potentiates expression of prostacyclin derivatives, and which, through feedback, lead to an even greater spasm of the microcirculation network of CNS. ${ }^{(8)}$ Experimental studies of the dynamics of neurotrophic factors in ischemic CNS lesions, and under neuroapoptosis, were performed only in newborns and pregnant women, and markers of endothelial dysfunction (Hcy and AII) were not taken into account. ${ }^{(9)}$ Results obtained in these studies do not fully correspond to the possibility of estimating the recovery period during the first year of life. In addition, there is currently no agreement between specialists in the choice of diagnostic neurobiochemical indicators as prognostic criteria reflecting the structural and functional damage to CNS, their dependence on clinical and instrumental examination, the severity of the condition, the timing of the initiation of treatment, or its duration, and the form of effective control. ${ }^{(10)}$ Evaluation of the level of physical development of children in any age range, correlated with other factors of analysis, allows us to provide a full clinical picture of the pathological process. ${ }^{(11)}$ Physical development of the child is the result of a combination of many factors, and the achieved indicators are unique for each child. The large variability of normal rates of development, determined by the complex interactions of a genetically determined response to a range of environmental conditions, significantly complicates the timely detection of the consequences of perinatal CNS lesions. ${ }^{(12,13)}$ Currently, it is far from uncommon that with a well-flowing pregnancy and childbirth, a child may be neurologically compromised, and a perinatal lesion diagnosed in the neonatal period may subsequently manifest in each child differently - from a persistent ND to the complete absence of clinical manifestations. This multi-vector state of the problem led to profile practitioners facing difficulties in establishing the diagnosis of perinatal damage of CNS, and the "transiency" of neurological manifestations often postpones the formulation of a correct diagnosis and leads to the untimely pathogenetic therapy for the underlying disease, leading to irreversible psycho-neurological effects.

Thus, competent and timely correction of the level of neurotrophic factors will avoid cerebral microcirculatory alterations and significantly reduce the disneyrometabolism, the risk of cognitive impairment, and also will allow early diagnosis of the latent effects of perinatal CNS lesions.

The purpose of this study was to evaluate the blood level of neurotrophic factors (S100 protein, NGF, L-Hcy and AII) in the diagnosis of disorders of the psychomotor and physical development of children who underwent perinatal CNS lesions.

\section{Materials and Methods}

The study included 419 patients (52\% boys and $48 \%$ girls) aged from 0 to 6 months. The main group (Group 1) included 336 patients in the first year of life who received inpatient treatment because of perinatal CNS damage of a different degree of severity. The control group (Group 2) included 83 apparently healthy children. Children in the control group passed standard clinical examinations in specified periods of observation at the stage of outpatient services. There were several obligatory criteria for patients to be included in the control group: absence of neurological symptoms, absence of a neurologist's supervision, and pharmacotherapy of neurological deviations during the first year of life.

Groups 1 and 2 were each divided into two subgroups according to age: Group 1a $(n=163)$ and Group 2a $(n=43)$ between the ages of 1 to 3 months; Group $1 b(n=173)$ and Group $2 b(n=40)$ between the ages of 4 to 6 months. In accordance with the ND severity (YA Yakunin's classification, 1979), Group 1a and Group 1b was also divided into subgroups: mild degree $(\mathrm{n}=122)$, moderate degree $(\mathrm{n}=118)$, and severe degree $(\mathrm{n}=96)$.

To assess the risk factors and the dynamics of clinical manifestations of the perinatal CNS damage consequences, we evaluated the women's somatic health, reproductive and gynecological history, and peculiarities of the course and complications of pregnancy and childbirth, using a scale of the optimal course of gestation (SOCG) and a scale of the optimal course of delivery (SOCD). ${ }^{(8)}$ To assess the severity of perinatal CNS damage, the Apgar score at birth was taken into account. ${ }^{(9)}$ The consequences of the severity of the perinatal CNS damage was established during a neurologic examination and evaluation of the children's neurological status. ${ }^{(14)}$ The analysis of individual physical development of the children was carried out using $\mathrm{Z}$ score (weight-for-age) and centiles (7 intervals ("corridors")) according to the WHO standard program WHO AnthroPlus. ${ }^{(10-12)}$ The average Z-score of weightfor-age (WAZ) was determined. The obtained Z-score data were correlated with centile intervals as follows: 4-5 - "normal" physical development; 3 and 6 - physical development "below average" and "above average," respectively; 2 and 7 - physical development "low" and "high,"; 1 and 8 - "very low" and "very high" physical development, respectively.

The concentrations of biochemical markers in the blood were evaluated in all children at admission, as a routine entry investigation. The serum level of the beta subunit of human NGF (beta-NGF) was measured by EIA (BetaNGF, «RayBio», Russia.). The serum level of L-Hcy was determined by EIA using «Axis-Shield» test kit. S100 protein was evaluated by means of the ELISA method, with the Cobas e411 analyser (Roche Diagnostics GmbH, Germany) and reagents by BioKhimMak (Russia). The serum level of AII was determined by using EIA kits according to manufacturer instructions (BCM Diagnostics, Moscow, Russia).

The study was approved by the Voronezh State Medical University Ethics Committee (Protocol No. 6 of October 19, 2013). Written informed consent was obtained from the child's parents.

Statistical analysis was performed using StatSoft Statistica v6.0. Multiple comparisons were performed with one-way ANOVA and post-hoc Tukey HSD test. A probability value of $P<0.05$ was considered statistically significant. 


\section{Results and Discussion}

An analysis of the frequency of identified neurologic syndromes in patients of the main group by age, depending on the severity of the CNS lesion, is presented in Table 1. The results obtained established that, regardless of age, the incidence of neurologic syndromes increased with an increase in the severity of the CNS lesion. It should be noted that in Group 1a, regardless of the degree of severity of the CNS lesion, hyperexcitability syndrome was dominant, to which the syndrome of motor disorders was added at a severe degree of CNS damage. In Group 1b, a syndrome of motor disorders and a syndrome of delayed psychomotor development were dominant (Table 1).

\section{Table 1.}

The frequency of neurologic syndromes in newborns with perinatal CNS lesions, depending on the ND severity and age group

\begin{tabular}{|l|c|c|c|c|c|c|}
\hline & \multicolumn{2}{|c|}{$\begin{array}{c}\text { Mild degree } \\
\text { of ND } \\
(\mathrm{n}=112)\end{array}$} & \multicolumn{2}{c|}{$\begin{array}{c}\text { Moderate } \\
\text { degree of ND } \\
(\mathrm{n}=118)\end{array}$} & \multicolumn{2}{c|}{$\begin{array}{c}\text { Severe degree } \\
\text { of ND } \\
(\mathrm{n}=96)\end{array}$} \\
\cline { 2 - 7 } Clinical syndrome & $\begin{array}{c}1-3 \\
\text { months } \\
(\mathrm{n}=60)\end{array}$ & $\begin{array}{c}4-6 \\
\text { months } \\
(\mathrm{n}=62)\end{array}$ & $\begin{array}{c}1-3 \\
\text { months } \\
(\mathrm{n}=58)\end{array}$ & $\begin{array}{c}4-6 \\
\text { months } \\
(\mathrm{n}=60)\end{array}$ & $\begin{array}{c}1-3 \\
\text { months } \\
(\mathrm{n}=45)\end{array}$ & $\begin{array}{c}4-6 \\
\text { months } \\
(\mathrm{n}=51)\end{array}$ \\
\hline $\begin{array}{l}\text { Syndrome of motor } \\
\text { disorders (n/\%) }\end{array}$ & $7 / 11.7$ & $4 / 6.4$ & $15 / 25.9$ & $16 / 26.7$ & $21 / 46.7$ & $17 / 33.3$ \\
\hline $\begin{array}{l}\text { Posthypoxic } \\
\text { ventricular } \\
\text { dilatation (n/\%) }\end{array}$ & $2 / 3.3$ & $1 / 1.6$ & $7 / 12.1$ & $3 / 5$ & $13 / 28.9$ & $5 / 9.8$ \\
\hline $\begin{array}{l}\text { Vegetative-visceral } \\
\text { dysregulation } \\
\text { (n/\%) }\end{array}$ & $1 / 1.7$ & $1 / 1.6$ & $4 / 6.9$ & $8 / 13.3$ & $4 / 8.9$ & $6 / 11.8$ \\
\hline $\begin{array}{l}\text { Hyperexcitability } \\
\text { syndrome (n/\%) }\end{array}$ & $7 / 11.7$ & 0 & $19 / 32.8$ & 0 & $6 / 13.3$ & $1 / 1.96)$ \\
\hline $\begin{array}{l}\text { Syndrome } \\
\text { of delayed } \\
\text { psychomotor } \\
\text { development (n/\%) }\end{array}$ & 0 & $2 / 3.2$ & $1 / 1.7$ & $9 / 15$ & $2 / 4.4$ & $12 / 23.5$ \\
\hline
\end{tabular}

Assessment of the physical and psychomotor states of the children revealed significant differences in accordance with the severity of the CNS lesion (Table 2). The received results testify to a decrease in all investigated parameters against the background of increased severity of the CNS lesion.

The blood levels of biochemical markers of CNS damage are presented in Table 3. Thus, a mild degree of CNS lesion was associated with increased levels of neurotrophic and vascular markers, reflecting both the pathological and compensatory nature of the changes. The average and severe degrees of CNS lesions were accompanied by a decreased level of all parameters, which indicates more pronounced and organically irreversible consequences of damage to brain structures.

It should be noted that the age period of 1-3 months is characterized by a decrease in both neuronal loss and the severity of neurological disorders, which is especially important for the timely diagnosis of ND. In the age period of 4-6 months, there is an aggravation of neurodystrophic processes, a rupture of synaptic connections, and a disruption in the interaction of different areas of the brain. All of which determine a broader clinical picture of neurologic symptoms in this age group.

Thus, a comprehensive approach to assessing the blood levels of neurotrophic factors, along with methods of neuroimaging in children in the first 6 months of the postnatal period, allows identification of the total result of multidirectional degenerative-reparative processes in the neurovascular components of CNS and construction of the diagnostically significant criteria of the severity of neuropathology, which determines the physical development of children in the first year of life:

1. With a mild degree of the CNS lesion, a slight increase in the content of S100 protein and NGF (no more than $15 \%$ of the norm) in the age group of 1-3 months is determined. The presence of physical development "above average" is found, regardless of the age group.

Table 2.

The physical and psychomotor states of the children and the severity of the CNS lesion (M $\pm S E M)$

\begin{tabular}{|c|c|c|c|c|c|c|c|c|}
\hline \multirow[b]{2}{*}{ Variable } & \multirow{2}{*}{$\begin{array}{c}\text { Control } \\
\text { group }\end{array}$} & \multicolumn{2}{|c|}{ Mild degree of ND } & \multicolumn{2}{|c|}{ Moderate degree of ND } & \multicolumn{2}{|c|}{ Severe degree of ND } & \multirow[b]{2}{*}{ Statistics } \\
\hline & & $\begin{array}{c}\text { Group 1a } \\
(\mathrm{n}=60)(1)\end{array}$ & $\begin{array}{l}\text { Group } 1 b \\
(\mathrm{n}=62)(2)\end{array}$ & $\begin{array}{l}\text { Group 1a } \\
(\mathrm{n}=58)(3)\end{array}$ & $\begin{array}{l}\text { Group } 1 b \\
(n=60)(4)\end{array}$ & $\begin{array}{l}\text { Group 1a } \\
(n-45)(5)\end{array}$ & $\begin{array}{l}\text { Group } 1 b \\
(n=51)(6)\end{array}$ & \\
\hline SOCG (\%) & $77 \pm 3$ & $63 \pm 4$ & $62 \pm 4$ & $51 \pm 6$ & $50 \pm 3$ & $34 \pm 4$ & $36 \pm 3$ & $\begin{array}{l}\text { Group 1a: } \mathrm{F}=8.3469 \mathrm{P}=0.0004 \\
\mathrm{P}_{1-5}=0.0002, \mathrm{P}_{3-5}=0.0486 \\
\text { Group 1b: } \mathrm{F}=13.9444, \mathrm{P}=0.0000 \\
\mathrm{P}_{2-4}=0.0316, \mathrm{P}_{2-6}=0.0000, \mathrm{P}_{4-6}=0.0147\end{array}$ \\
\hline SOCD (\%) & $67 \pm 4$ & $58 \pm 3$ & $57 \pm 2$ & $44 \pm 3 *$ & $43 \pm 3$ & $37 \pm 3$ & $34 \pm 3$ & $\begin{array}{l}\text { Group 1a: } \mathrm{F}=12.3615 \mathrm{P}=0.0000 \\
\mathrm{P}_{1-3-0}=0.0023, \mathrm{P}_{1-5}=0.0000 \\
\text { Group 1b: } \mathrm{F}=18.6146, \mathrm{P}=0.0000 \\
\mathrm{P}_{2-4}=0.0006, \mathrm{P}_{2-6}=0.0000\end{array}$ \\
\hline Apgar score & $7 \pm 1$ & $6 \pm 1$ & $5 \pm 1$ & $5 \pm 1$ & $5 \pm 1$ & $4 \pm 1$ & $4 \pm 1$ & $\begin{array}{l}\text { Group 1a: } \mathrm{F}=0.9392 \mathrm{P}=0.3931 \\
\text { Group 1b: } \mathrm{F}=0.3097, \mathrm{P}=0.7341\end{array}$ \\
\hline Z score (WAZ) & $0 \pm 0.8$ & $0.9 \pm 0.2$ & $1.0 \pm 0.1$ & $1.4 \pm 0.1$ & $1.5 \pm 0.1$ & $1.9 \pm 0.1$ & $2.1 \pm 0.1$ & $\begin{array}{l}\text { Group 1a: } \mathrm{F}=10.6572 \mathrm{P}=0.0000 \\
\mathrm{P}_{1-3}=0.0392, \mathrm{P}_{1-5}=0.0000 \\
\text { Group 1b: } 29.1534, \mathrm{P}=0.0000 \\
\mathrm{P}_{2-4}=0.0011, \mathrm{P}_{2-6}=0.0000, \mathrm{P}_{4-6}=0.0002\end{array}$ \\
\hline
\end{tabular}


Table 3.

Blood levels of neurotrophic factors and the severity of the CNS lesion (M $\pm S E M)$

\begin{tabular}{|c|c|c|c|c|c|c|}
\hline $\begin{array}{l}\text { Age group } \\
\text { (month) }\end{array}$ & Variable & $\begin{array}{l}\text { Control } \\
\text { group (1) }\end{array}$ & $\begin{array}{l}\text { Mild degree } \\
\text { of ND (2) }\end{array}$ & $\begin{array}{l}\text { Moderate degree } \\
\text { of ND (3) }\end{array}$ & $\begin{array}{l}\text { Severe degree } \\
\text { of ND (4) }\end{array}$ & Statistics \\
\hline \multirow{4}{*}{$1-3$ months } & $\begin{array}{l}\text { S-100 } \\
(\mathrm{pg} / \mathrm{ml})\end{array}$ & $231.2 \pm 24.7$ & $270.4 \pm 17.6$ & $337.8 \pm 14.7$ & $169.05 \pm 15.4$ & $\begin{aligned} \mathrm{F} & =15.2345 \mathrm{P}=0.0000 \\
\mathrm{P}^{1-3} & =0.0000, \mathrm{P}_{2-3}=0.0000 \\
\mathrm{P}_{2-4} & =0.0000, \mathrm{P}_{3-4}=0.0000\end{aligned}$ \\
\hline & $\begin{array}{l}\text { NGF } \\
(\mathrm{pg} / \mathrm{ml})\end{array}$ & $287.6 \pm 16.3$ & $312.1 \pm 11.9$ & $264.1 \pm 13.4$ & $207.25 \pm 12.8$ & $\begin{aligned} \mathrm{F} & =10.5940 \mathrm{P}=0.0000 \\
\mathrm{P}_{1-4} & =0.0008, \mathrm{P}_{2-3}=0.0386 \\
\mathrm{P}_{2-4} & =0.0000, \mathrm{P}_{3-4}=0.0184\end{aligned}$ \\
\hline & $\begin{array}{c}\text { L-Hcy } \\
(\mu \mathrm{mol} / \mathrm{ml})\end{array}$ & $4.9 \pm 0.8$ & $6.87 \pm 0.91$ & $6.06 \pm 0.99$ & $7.4 \pm 1.01$ & $\mathrm{~F}=1.1606 \mathrm{P}=0.3259$ \\
\hline & $\underset{(\mathrm{ng} / \mathrm{ml})}{\mathrm{AII}}$ & $0.09 \pm 0.01$ & $0.06 \pm 0.01$ & $0.07 \pm 0.05$ & $0.041 \pm 0.03$ & $\mathrm{~F}=0.3547 \mathrm{P}=0.7858$ \\
\hline \multirow{4}{*}{ 4-6 months } & $\begin{array}{c}\text { S-100 } \\
(\mathrm{pg} / \mathrm{ml})\end{array}$ & $242.2 \pm 61.7$ & $341.55 \pm 15.3$ & $333.8 \pm 18.7$ & $341.55 \pm 19.3$ & $\mathrm{~F}=2.3649 \mathrm{P}=0.0721$ \\
\hline & $\begin{array}{l}\text { NGF } \\
(\mathrm{pg} / \mathrm{ml})\end{array}$ & $287.6 \pm 26.3$ & $298.2 \pm 12.6$ & $255.3 \pm 18.2$ & $298.2 \pm 11.6$ & $\mathrm{~F}=1.5856 \mathrm{P}=0.1939$ \\
\hline & $\begin{array}{c}\mathrm{L}-\mathrm{Hcy} \\
(\mu \mathrm{mol} / \mathrm{ml})\end{array}$ & $4.9 \pm 0.8$ & $6.51 \pm 1.91$ & $5.61 \pm 0.61$ & $5.51 \pm 0.91$ & $\mathrm{~F}=0.2691 \mathrm{P}=0.8527$ \\
\hline & $\underset{(\mathrm{ng} / \mathrm{ml})}{\mathrm{AII}}$ & $0.08 \pm 0.6$ & $0.08 \pm 0.03$ & $0.105 \pm 0.05$ & $0.04 \pm 0.01$ & $\mathrm{~F}=0.0143 \mathrm{P}=0.9977$ \\
\hline
\end{tabular}

2. With a moderate degree of the CNS lesion, a significant increase in the blood content of S100 protein (an average of $45 \%$ of the norm) is determined in the age group of 1-3 months. Physical development at a moderate degree of the CNS lesion is characterized as "above average" in the age group of 1-3 months and "below average" in the age group of 4-6 months.

3. With a severe degree of the CNS lesion, the blood levels of NGF decreased by $28 \%$ relative to normal indices in the age group of 1-3 months. The physical development of these children was "very low."

\section{Competing interests} interests.

The authors declare that they have no competing

\section{Sources of Funding}

The study was carried out within the framework of the project "The regularities of morpho- and immunogenesis in clinical and experimental practice" (State Project No. 281 dated 04.30.2013).

\section{References}

1. Afanasyeva NV, Strizhakov AV. [Outcomes of pregnancy and childbirth with fetoplacental insufficiency of various severity]. Problems of Gynecology, Obstetrics and Perinatology. 2004;3(2):7-13. [Article in Russian].

2. Balakireva EA, Krasnorutskaya ON, Kalmykova GV. [Unresolved issues of pediatric neurology]. Scientific bulletins of Belgorod State University. Series: Medicine. Pharmacia. 2014;28.(24-1):5-7. [Article in Russian].

3. Barashnev YuI. [Hypoxic encephalopathy: hypotheses of the pathogenesis of cerebral disorders and the search for methods of drug therapy]. Rossiyskiy Vestnik Perinatologii Pediatrii. 2002; 1:6-13. [Article in Russian].

4. Golosnaia GS. [The role of inhibitors of apoptosis in the diagnosis and prediction of outcomes of perinatal hypoxic brain lesions in newborns]. Pediatria. 2005;84(3):30-35. [Article in Russian].

5. Zhurba LT. Mastyukova EM. [Disturbances in the psychomotor development of children of the first year of life]. M.: Meditsina; 1981. [In Russian].

6. Krasnorutckaya ON, Balakireva EA, Zu'kova AA, Dobrynina IS. [Assessment of Biochemical Markers of Perinatal Injuries of Central Nervous System in the Children]. Journal of New Medical Technologies. 2014;21(2):26-29. [Article in Russian].

7. Lobanova LV. Hypoxic lesions of the brain in term infants - causes, pathogenesis, clinical and ultrasound diagnostics, prognosis and tactics of conducting children at an early age. Abstract of ScD Thesis. Ivanovo; 2000. [In Russian].

8. Palchik AB, Shabalov NP. Hypoxic-ischemic encephalopathy of newborns. 2nd ed. M: Medpressinform; 2009. [In Russian]. 
9. Baturin AK, Keshabyants EE, Martinchik AN, Peskova EV. [Retrospective assessment of anthropometric measurements of children in Russia 1994-2012 according to the new WHO standards. Pediatria]. 2015;94(1):156-160. [Article in Russian].

10. Esser S, Lampugnani MG, Corada M, Dejana E, Risau W. Vascular endothelial growth factor induces VE-cadherin tyrosine phophorylation in endothelial cells. J Cell Sci. 1998;111(Pt 13):1853-65.

11. Kainer F, Prechtl HF, Engale H, Einspieler C. Assessment of the quality of general movements in fetuses and infants of women with type-I diabetes mellitus. Early Hum Dev. 1997;50(1):13-25. 12. WHO growth reference. WHO AnthroPlus software [Electronic resourse]. Available from: http://www.who.int/ growthref/tools/en/.

13. de Onis M, Garza C, Onyango AW, Rolland-Cachera MF; le Comité de nutrition de la Société française de pédiatrie. [WHO growth standards for infants and young children]. Arch Pediatr. 2009;16(1):47-53. doi: 10.1016/j.arcped.2008.10.010. [Article in French].

14. Petrukhin AS. Neurology of childhood. M., 2004. [In Russian]. 